\title{
Badania laboratoryjne nad doborem środków przeciwakrecyjnych do płuczek wiertniczych
}

\section{Laboratory tests on the selection of anti-accretion agents in water-based drilling muds}

\author{
Sławomir Błaż \\ Instytut Nafty i Gazu - Państwowy Instytut Badawczy
}

\begin{abstract}
STRESZCZENIE: Podczas wiercenia otworów w formacjach łupkowych bardzo często występują poważne problemy związane z niestabilnością otworu wiertniczego. Większość z nich nie wynika z niskiej wytrzymałości mechanicznej przewiercanych skał, ale z ich chemicznie reaktywnego charakteru. Reaktywne skały ilasto-łupkowe pod wpływem płuczek wodnodyspersyjnych ulegają hydratacji. Uwodnione zwierciny przywierają do powierzchni świdra i metalowych części przewodu wiertniczego (rury płuczkowe, obciążniki), tworząc w ten sposób plastyczną mieszaninę, która przeciwdziała bezpośredniemu stykaniu się części wiercącej świdra z powierzchnią urabianej skały. Nadmierny wzrost zawartości rozmokniętej ilastej mieszaniny plastycznej na świdrze i przewodzie wiertniczym wpływa na proces wiercenia poprzez zwiększenie momentu obrotowego. W wyniku zwiększonego oporu może nastąpić przychwycenie przewodu, pogorszenie wskaźników hydraulicznych, co wpływa na zmniejszenie prędkości wiercenia otworu (ROP). W artykule przedstawiono badania nad doborem i wdrożeniem dodatku do wodnodyspersyjnych płuczek wiertniczych nowego rodzaju środka przeciwakrecyjnego zapobiegającego oblepianiu świdra i akrecji zwiercin na przewodzie wiertniczym. Badania skuteczności doboru środków do płuczek wiertniczych były prowadzone według założonej i opracowanej charakterystycznej metodologii badania, uwzględniającej wpływ poszczególnych czynników na zredukowanie zjawiska akrecji. Przeprowadzono szereg testów akrecyjnych określających wpływ rodzaju przewiercanej skały, czasu ekspozycji zwiercin na działanie płuczki, wpływ wielkości powstających zwiercin oraz występującego mechanicznego obciążenia na zjawisko akrecji. Badania doboru środków przeciwakrecyjnych prowadzono na próbkach skał odkrywkowych w środowisku wodnodyspersyjnych płuczek wiertniczych. Uzyskane wyniki zostały poddane analizie, umożliwiającej opracowanie składu środka przeciwakrecyjnego, który może być wykorzystywany jako dodatek do wodnodyspersyjnych płuczek wiertniczych zapobiegający oblepianiu świdra i akrecji zwiercin. Zastosowanie opracowanego środka do płuczek otworowych pozwoliło na ponad 90-procentowe zredukowanie akrecji zwiercin w porównaniu do płuczek bez dodatku tego typu środków. W badaniach potwierdzono także jego znacznie wyższą efektywność W stosunku do obecnie stosowanego w polskim wiertnictwie środka do zapobiegania oblepianiu świdra.
\end{abstract}

Słowa kluczowe: płuczka wodnodyspersyjna, akrecja zwiercin, oblepianie świdra, skały ilasto-łupkowe.

ABSTRACT: In the course of borehole drilling through shale formations very often there are serious problems associated with the instability of the borehole. Most of these problems do not result from the low mechanical strength of the drilled rocks, but from the chemically reactive nature of the rocks. Reactive shale-clay rocks are hydrated under the influence of water-based drilling muds. Hydrated cuttings at the bottom of the borehole adhere to the surface of the bit and metal parts of the drill string (drill pipes, drill collars), forming a plastic mixture that prevents direct contact between the drill blades and the surface of the rock to be cut. The excessive increase in the contents of the clayey plastic mixture on the bit and the drill pipe affects the drilling process by increasing the torque. As a result of the increased resistance, the pipe may get stuck, hydraulic indicators may deteriorate, which reduces the rate of penetration (ROP). This article presents research on the selection and implementation of a new type of anti-precipitation agent to water-based drilling muds, preventing the sticking of the bit and accretion of cuttings on the drill string. The selection of anti-accretion agents was carried out ac-cording to the methodology considering the influence of individual factors to reduce the accretion phenomenon. A number of accretion tests were carried out to determine the effect of the type of rock used, the exposure time of the drill cuttings to drilling mud influence, the impact of the size of the formed cuttings and the mechanical load on the accretion phenomenon. Studies on the selection of anti-accretion agents were carried out on open-pit rock samples in the environment of water-based drilling muds. The obtained results were analyzed allowing the formulation of the anti-accretion composition, which can be used as an additive to water-based drilling muds, preventing the drilling bit from getting stuck and the accretion of cuttings. The use of the developed agent has allowed for more than $90 \%$ reduction of accretion of drill cuttings compared to muds without the addition of this type of agent, as well as its much higher efficiency than the anti-accretion agent used in the Polish drilling industry.

Key words: water-based drilling mud, cutting accretion, bit balling, clay-shale rocks.

Autor do korespondencji: S. Błaż, e-mail: slawomir.blaz@inig.pl

Artykuł nadesłano do Redakcji 11.01.2019. Zatwierdzono do druku 19.04.2019 r. 


\section{Wprowadzenie}

Ze zjawiskiem akrecji w otworze wiertniczym mamy do czynienia głównie podczas przewiercania warstw ilasto-łupkowych. Powstałe podczas przewiercania formacji łupkowych zwierciny pod wpływem filtratu z płuczki wodnodyspersyjnej ulegają głównie rozmakaniu i pęcznieniu. Towarzysząca rozmakaniu dyspersja zwiercin prowadzi także do powstania nadmiaru rozproszonej fazy stałej w płuczce wiertniczej. Szybkość uwodnienia i ilość zaadsorbowanej wody przez zwierciny w dużym stopniu zależy od składu mineralnego przewiercanej skały ilastej, struktury minerałów, a także braku równowagi jonowej między skałą a płuczką. Uwodnione zwierciny na dnie otworu wiertniczego ulegają aglomeracji, przyklejając się do świdra wiertniczego oraz przewodu wiertniczego (rur płuczkowych, obciążników). Zjawisko to często jest określane jako „akrecja” (Mat et al., 2002; Judzis et al., 2007; Black et al., 2008; Mettath et al., 2011, Onuoha et al., 2011; He et al., 2016). Akrecję najczęściej tłumaczy się poprzez zwiększenie plastyczności zwierconych części skał ilasto-łupkowych. Koncepcja plastyczności skał ilasto-łupkowych przyczyniającej się do akrecji zakłada, że w płuczkach wodnodyspersyjnych zawierających inhibitory hydratacji skał ilasto-łupkowych, takie jak poliglikole, krzemiany, związki aminowe, szybkość uwodnienia łupku ilastego zostaje spowolniona w taki sposób, że zwierciny pozostają w stanie plastycznym przez dłuższy czas. Uważa się, że ten utrzymujący się stan plastyczności przyczynia się do aglomeracji zwiercin i przyklejania się ich do stalowych części przewodu wiertniczego oraz do ściany otworu. Nadmierny wzrost zawartości rozmokniętej ilastej mieszaniny plastycznej na świdrze i przewodzie wiertniczym wpływa na proces wiercenia poprzez zwiększenie momentu obrotowego. W wyniku zwiększonego oporu może nastąpić przychwycenie przewodu, pogorszenie wskaźników hydraulicznych, co tym samym wpływa na zmniejszenie prędkości wiercenia otworu (Hariharan et al., 1998; Van Oort et al., 2000, 2015; Cliffe i Young, 2008; Jasiński, 2015; Van Oort, 2017; Villabona-Estupiñán et al., 2017).

Ze znacznie większym ryzykiem wystąpienia zjawiska akrecji zwiercin na przewodzie wiertniczym mamy do czynienia podczas przewiercania reaktywnych skał ilasto-łupkowych za pomocą płuczek wodnodyspersyjnych. Składy wodnodyspersyjnych płuczek wiertniczych na przestrzeni ostatnich lat uległy zmianie, opracowano wiele nowych rozwiązań, wprowadzając m.in. nowy rodzaj płuczki wiertniczej HPWBM (High Performance Water-Based Mud). Wraz z wdrożeniem do wierceń nowej generacji płuczek wiertniczych HPWBM zawierajacych w swoim składzie nowe rodzaje związków chemicznych (aminy, poliaminy, polieteroaminy) mających na celu zmniejszenie lub znaczące opóźnienie ich interakcji ze skałami ilasto-łupkowymi problemy niestabilności otworu zostały znacznie ograniczone (Ewy i Morton, 2009; Zhang et al., 2015; Yadav et al., 2016; Uliasz et al., 2018). Jednak niedogodności związane z oblepianiem świdra, aglomeracją i akrecją zwiercin w otworze nadal występują. Powyższe kwestie próbuje się rozwiązywać poprzez dobór rodzaju świdrów do danej formacji, zmiany konstrukcyjne ich budowy oraz poprawę hydrauliki systemu wiercącego. Innym ze sposobów zapobiegania oblepianiu świdra i aglomeracji zwiercin na metalowych częściach wyposażenia wgłębnego otworu jest możliwość zastosowania zjawiska elektroosmozy lub osmozy chemicznej. Znane są również metody pokrywania powierzchni świdrów specjalną polietylenową powłoką adhezyjną zmniejszającą potencjał akrecji zwiercin (Smith et al., 1996; Wells et al., 2008; Ma et al., 2012, Rahmani et al., 2016; Schnuriger et al., 2017).

Jednym z najbardziej uniwersalnych i ekonomicznie uzasadnionych sposobów zapobiegania aglomeracji i akrecji zwiercin na świdrze i przewodzie wiertniczym jest możliwość stosowania w zależności od zagrożenia specjalistycznych środków chemicznych, które poprzez utworzenie na powierzchni zwiercin filmu hydrofobowego zmniejszą ich przyczepność do powierzchni stalowych przewodu wiertniczego oraz zapobiegną łączeniu się uwodnionych cząsteczek ilastych w większe aglomeraty. Przedstawione w artykule badania zostały ukierunkowane na zapobieganie akrecji zwiercin na świdrze i przewodzie wiertniczym poprzez dodawanie do płuczek środków przeciwakrecyjnych.

\section{Badania akrecji zwiercin na powierzchni metalowej w środowisku płuczek wiertniczych}

Do przeprowadzenia badań akrecji zastosowano dwa rodzaje łupków pochodzących z odkrywki: łupek eoceński i łupek mioceński o silnych właściwościach pęczniejących i dyspergujących. Zjawisko akrecji badano w laboratorium przy użyciu dwóch rodzajów prętów wykonanych ze stali miękkiej o wymiarach: długości $150 \mathrm{~mm}$, średnicy $25 \mathrm{~mm}$ i wadze: pręt stalowy ciężki 580 g, pręt stalowy lekki 121 g (fot. 1).
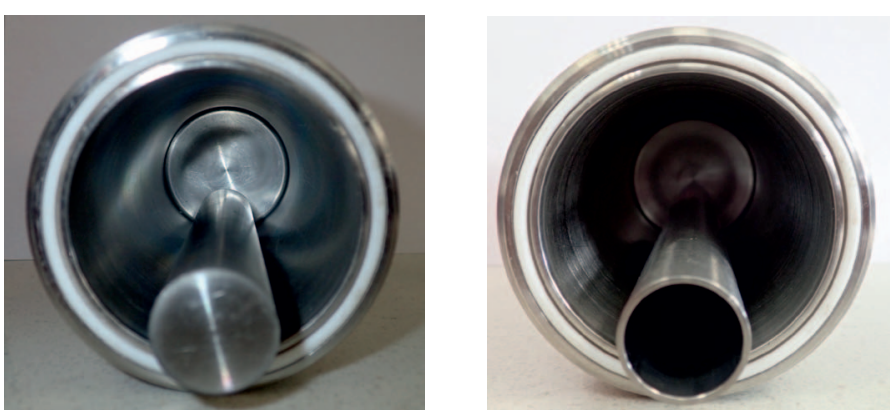

Fot. 1. Komora testowa do badań akrecji zwiercin

Phot. 1. Accretion Test Cell - Solid Steel Bar 
Przed przystąpieniem do testów pręty ze stali o znanej masie i wymiarach dokładnie przeszlifowano i oczyszczono, a następnie umieszczono w środku komory testowej ze stali nierdzewnej. Komorę testową wypełniono do połowy płuczką wiertniczą, następnie wprowadzono do niej $50 \mathrm{~g}\left(W_{1}\right)$ przygotowanej skały łupkowej (rozkruszonej i odpowiednio zwymiarowanej) i równomiernie rozprowadzono w całej objętości autoklawu. Komorę testową uzupełniono płuczką wiertniczą do określonego poziomu, uszczelniono, a następnie umieszczono w piecu obrotowym roller oven i poddano rolowaniu w ściśle określonym czasie. Po upływie założonego czasu pręt z przyklejonymi fragmentami skały łupkowej wyciągnięto $\mathrm{z}$ komory testowej, przemyto delikatnie wodą i pozostawiono na papierze do odcieknięcia nadmiaru wody. Następnie przyklejone do powierzchni metalowego pręta fragmenty uwodnionej skały ilasto-łupkowej zeskrobano na szklaną szalkę i zważono $\left(W_{2}\right)$. Po zważeniu usunięty osad łupkowy wysuszono w temperaturze $105^{\circ} \mathrm{C}$, a następnie ponownie zważono $\left(W_{3}\right)$. Akrecja jest obliczana ze wzoru:

$$
A=\frac{W_{3}}{\left[\frac{100-M_{i}}{100}\right] \cdot W_{1}}[\%]
$$

gdzie:

$A$ - akrecja zwiercin [\%],

$W_{1}$ - początkowa waga próbki $[\mathrm{g}]$,

$W_{2}$ - waga osadu iłowego usuniętego z powierzchni stalo-

wego pręta [g],

$W_{3}$ - waga wysuszonego osadu $[\mathrm{g}]$,

$M_{i}$ - początkowa zawartość wody w łupku.

Natomiast zawartość wody w osadzie iłowym usuniętym z powierzchni stalowego pręta obliczano ze wzoru:

$$
\% \mathrm{H}_{2} \mathrm{O}=\frac{\left(W_{3}-W_{2}\right) \cdot 100}{W_{2}}
$$

Badania akrecji zwiercin na metalowej powierzchni stalowego pręta prowadzono $\mathrm{w}$ środowisku zawiesiny polimerowo-iłowej, płuczki potasowo-polimerowej o zwiększonych parametrach reologiczno-strukturalnych oraz $\mathrm{w}$ środowisku płuczki otworowej pobranej podczas wiercenia otworu K1. akrecji na powierzchni metalowych prętów - badania przeprowadzono po czasie: 5, 10, 20, 30, 60 i 120 minut. Wartości akrecji w zależności od zastosowanego łupku przedstawiono na rysunku 1 i w tabelach od 2 do 3.

Przeprowadzone badania wykazały, że akrecja w dużym stopniu zależna jest od rodzaju zastosowanego łupku. Analizując otrzymane wartości akrecji, można stwierdzić, iż łupek eoceński ze względu na swoje właściwości charakteryzuje się znacznie większą tendencją do przywierania do stalowej powierzchni pręta w środowisku badanej cieczy. Maksymalna wartość akrecji dla łupku eoceńskiego, odnotowana po $20 \mathrm{mi}-$ nutach, wynosiła $94,9 \%$ (rys. 1, tab. 2, fot. 4), przy uwodnieniu próbki na poziomie $26,7 \%$ (rys. 2). Podobną wartość akrecji, wynoszącą 89,5\%, otrzymano dla łupku eoceńskiego po upływie 30 minut (rys. 1, tab. 2, fot. 5). Kolejne przeprowadzone testy wykazały znaczny spadek wartości akrecji wraz z upływem czasu. Po 1 godzinie akrecja zwiercin łupku eoceńskiego została ograniczona do poziomu $43,5 \%$ (tab. 2, fot. 6 ), a po 120 minutach spadła do wartości $23,5 \%$ (tab. 2, fot. 7 ).

Stopień akrecji łupku mioceńskiego w środowisku badanej cieczy jest znacznie mniejszy. Maksymalną wartość akrecji zwiercin łupku mioceńskiego na powierzchni metalowego pręta otrzymano już po czasie 10 minut i wynosiła ona $66,2 \%$ (rys. 1, tab. 3, fot. 9). Następnie zwiększenie czasu odziaływania zawiesiny polimerowo-iłowej do 30 min wpłynęło na znaczne obniżenie stopnia akrecji - do poziomu 37,9\% (tab. 3, fot. 11), a po 1 godz. do wartości 13,5\% (tab. 3, fot. 12). Po upływie 2 godz. nie obserwujemy zjawiska akrecji, zwierciny łupku mioceńskiego nie przyklejają się do powierzchni stalowego pręta (tab. 3, fot. 13).

$\mathrm{Na}$ rysunku 2 przedstawiono zmianę zawartości wody w zwiercinach, które uległy akrecji, w zależności od czasu. Zawartość wody w zwiercinach łupku mioceńskiego, które uległy akrecji, zawierała się w przedziale od $18 \%$ do $23,7 \%$. Natomiast uwodnienie zwiercin łupku eoceńskiego wynosiło od $17,6 \%$ przy najniższym stopniu akrecji do około $26,7 \%$ (rys. 2) przy maksymalnym stopniu akrecji. Wysoki stopień uwodnienia próbek skał ilasto-łupkowych może również sugerować możliwość wystąpienia akrecji.

\section{Wplyw rodzaju skaty ilasto- tupkowej na zjawisko akrecji}

Badania akrecji przeprowadzono dla łupku eoceńskiego i łupku mioceńskiego na frakcji zwiercin o rozmiarach od 2 do $5 \mathrm{~mm}$ w środowisku zawiesiny polimerowo-iłowej charakteryzującej się lepkością plastyczną $26 \mathrm{mPa} \cdot \mathrm{s}$ i granicą płynięcia 15,8 Pa (tab. 1). W celu określenia prędkości zachodzenia zjawiska
Tabela 1. Właściwości zawiesiny polimerowo-iłowej

Table 1. Properties of a polymer-clay suspension

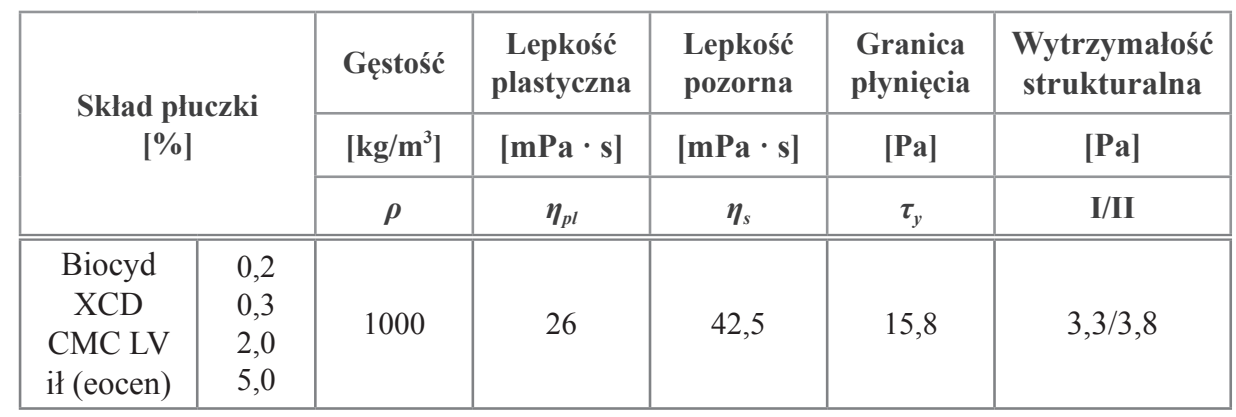




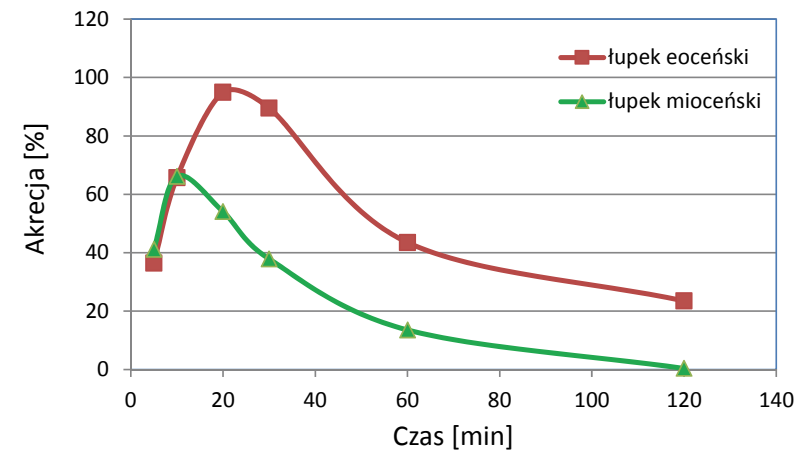

Rys. 1. Wpływ rodzaju skały ilasto-łupkowej na zjawisko akrecji zwiercin w zależności od czasu

Fig. 1. Effect of the shale rock type on the accretion of cuttings depending on time

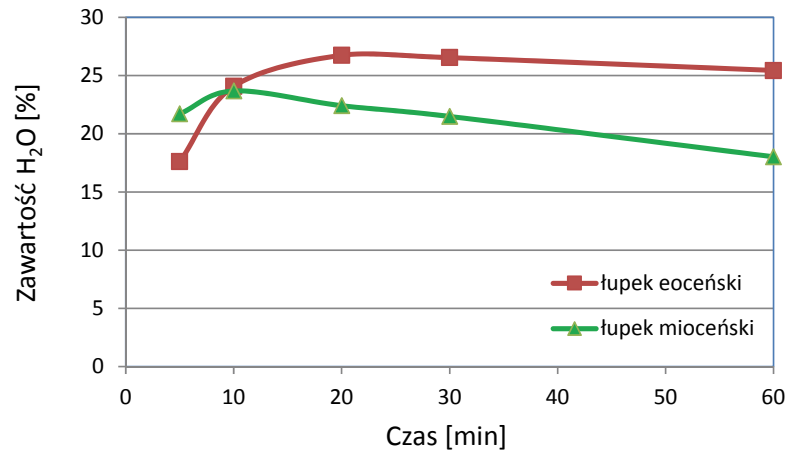

Rys. 2. Zawartość wody w próbkach skały ilasto-łupkowej w zależności od czasu i stopnia akrecji

Fig. 2. Water content in shale clay rock samples depending on the time and accretion degree

Tabela 2. Wartości akrecji zwiercin łupku eoceńskiego w zależności od czasu

Table 2. Accretion value of Eocene shale depending on time

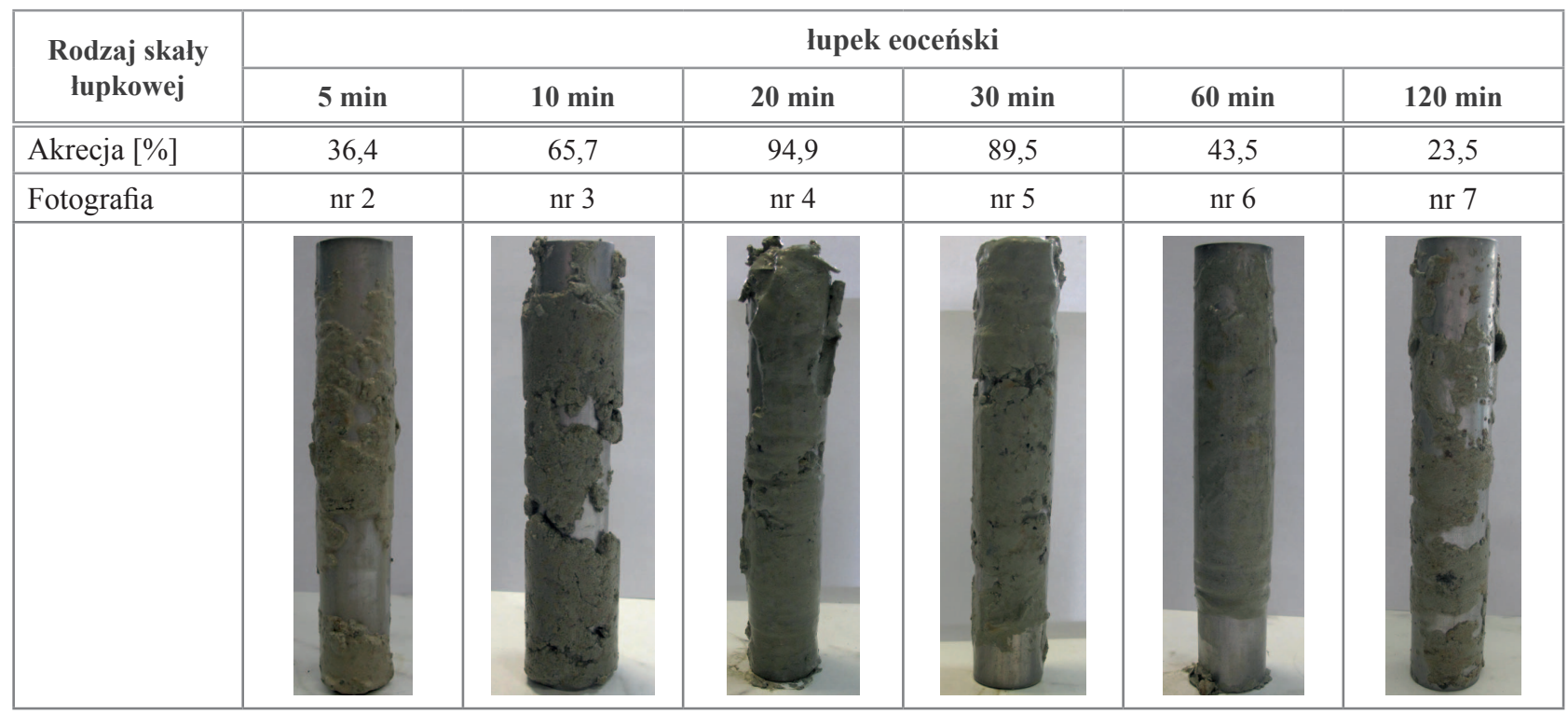

Tabela 3. Wartości akrecji zwiercin łupku mioceńskiego w zależności od czasu

Table 3. Accretion value of Miocene shale depending on time

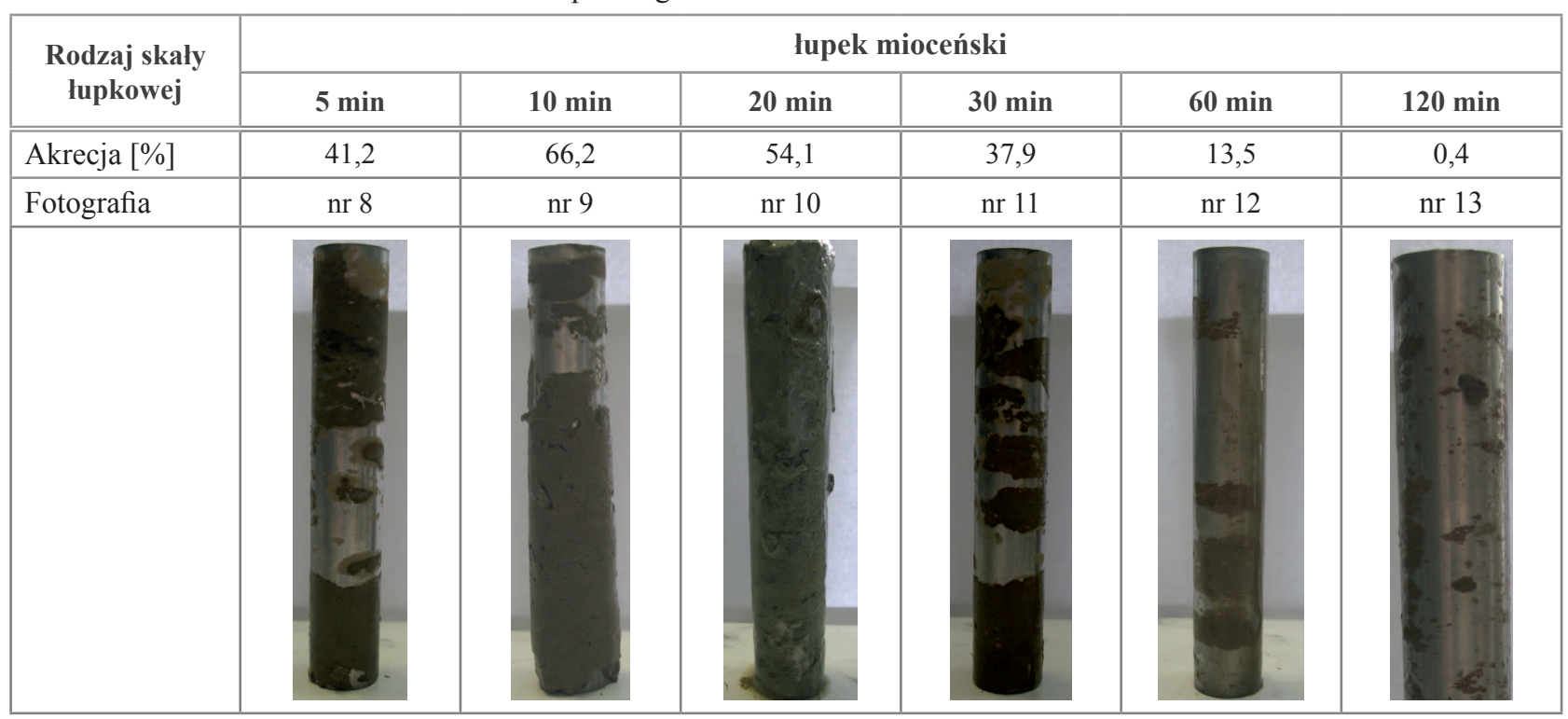


Zwierciny powstałe $\mathrm{z}$ badanych skał łupkowych, zanim zostaną przyklejone do metalowej powierzchni, podlegają, pod wpływem mechanicznego oddziaływania, procesowi odkształcania, a następnie aglomeracji. Zwierciny o częściowo zniszczonej strukturze adsorbują wodę z płuczki wiertniczej. Gdy zawartość wody w próbce skały ilasto-łupkowej przekroczy granicę plastyczności, zaczyna się proces przywierania uplastycznionej masy iłowej do metalowej powierzchni pręta stalowego i trwa on do momentu przekroczenia granicy płynności, czyli do chwili, gdy zwierciny pod wpływem wody ulegną dyspersji i rozproszeniu do poziomu, przy którym przestają być plastyczne.

Określone profile akrecyjne (rys. 1) badanych łupków różnią się między sobą. Łupek mioceński pod wpływem zawiesiny polimerowo-iłowej zaczyna się dość szybko osadzać na metalowej powierzchni pręta, następnie osiąga maksimum akrecji już po około $10 \mathrm{~min}$, a następnie uwadnia się do poziomu, przy którym przestaje być plastyczny, ulega dyspersji i silnemu rozproszeniu w środowisku badanej cieczy wiertniczej. Akrecja łupku eoceńskiego przebiega wolniej, maksymalny przyrost zwiercin na stalowym pręcie obserwujemy po upływie około 20-30 min, następnie ilość przyklejonych zwiercin do stalowego pręta wraz z upływem czasu ulega zmniejszeniu do poziomu $23,5 \%$ (rys. 1 ).

\section{Wpływ wielkości zwiercin na akrecje}

Badania akrecji w zależności od czasu przeprowadzono dla trzech klas wielkości zwiercin łupku eoceńskiego, tj. 1,4-2 mm, 2-5 $\mathrm{mm}$ i 5-7 mm. Uzyskane wyniki wartości akrecji w zależności od rozmiaru zwiercin przedstawiono na rysunku 3.

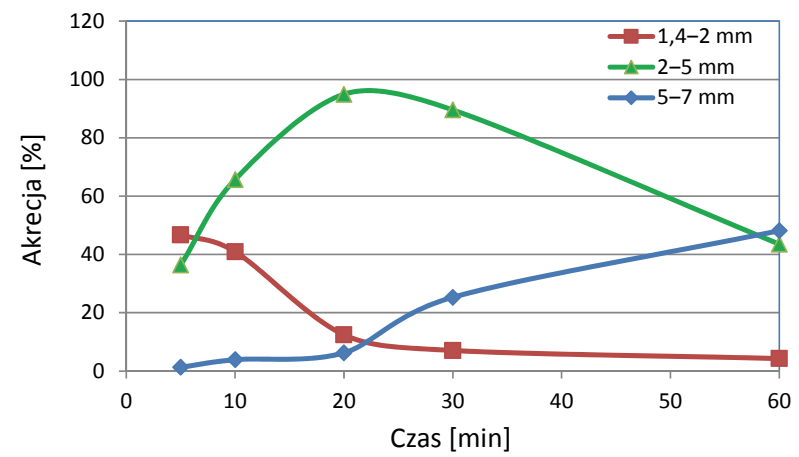

Rys. 3. Wpływ rozmiaru zwiercin łupku eoceńskiego na zjawisko akrecji

Fig. 3. Effect of Eocene shale cuttings size on the accretion phenomenon

Zwierciny o rozmiarach od $2 \mathrm{~mm}$ do $5 \mathrm{~mm}$ znacznie szybciej ulegają uwodnieniu, przechodząc w stan plastyczności, i zaczynają przywierać do powierzchni metalowych. Maksymalną wartość akrecji 94,92\% (rys. 3) stwierdzono już po czasie 20 min. Natomiast proces przeklejania zwiercin o rozmiarach od $5 \mathrm{~mm}$ do $7 \mathrm{~mm}$ zachodzi znacznie wolniej. Zwierciny dopiero po około 20 min rozpoczynają przywieranie do metalowej powierzchni pręta, a dopiero po około $60 \mathrm{~min}$ wartość akrecji osiąga $48,14 \%$ (rys. 3). Niższy poziom akrecji stwierdzono dla zwiercin o rozmiarach od 1,4 $\mathrm{mm}$ do $2 \mathrm{~mm}$. Maksymalną wartość akrecji uzyskujemy już po 5 min testu, a następnie akrecja zwiercin wraz z upływem czasu systematycznie ulega obniżeniu, by po około 20 min zwierciny przestały się przyklejać do metalowej powierzchni pręta (rys. 3).

Na podstawie otrzymanych wyników ustalono, że wraz ze wzrostem wielkości zwiercin następuje opóźnienie procesu akrecji oraz obniżenie jej wartości. Zwierciny o rozmiarach od $5 \mathrm{~mm}$ do $7 \mathrm{~mm}$ wymagają znacznie dłuższego czasu oddziaływania płuczki i obciążenia mechanicznego na rozpoczęcie procesu akrecji zwiercin. Biorąc pod uwagę otrzymane wyniki, można sądzić, iż wytwarzane podczas wiercenia zwierciny o większych rozmiarach będą charakteryzować się mniejszą tendencją do akrecji na przewodzie wiertniczym - pod warunkiem zoptymalizowania hydrauliki do szybkiego usunięcia zwiercin z dna otworu.

\section{Wphyw odzialywania mechanicznego obciażenia na zjawisko akrecji}

Wpływ obciążenia mechanicznego na wartość akrecji zwiercin został określony za pomocą dwóch testów porównawczych, w których do badania zastosowano dwa rodzaje prętów stalowych: pręt stalowy ciężki o wadze $580 \mathrm{~g}$ i pręt stalowy lekki o wadze $108 \mathrm{~g}$ (fot. 1). Badania przeprowadzono w środowisku zawiesiny polimerowo-iłowej (tab. 1) na zwiercinach wytworzonych z łupku eoceńskiego o rozmiarach od $2 \mathrm{~mm}$ do $5 \mathrm{~mm}$.

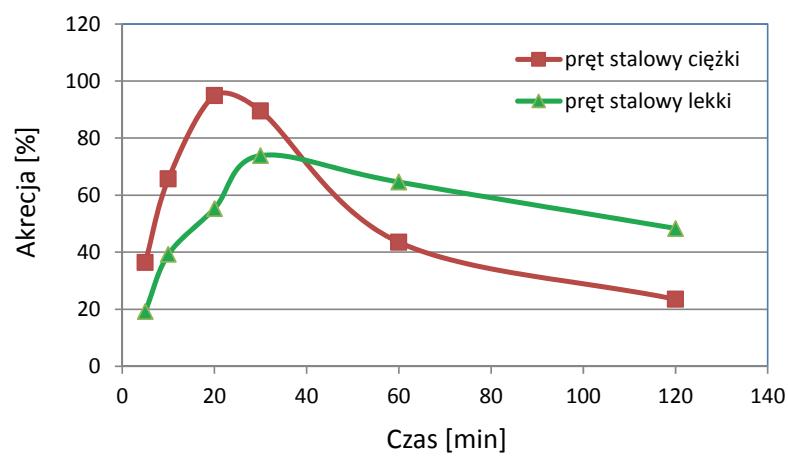

Rys. 4. Wpływ obciążenia mechanicznego na wartość akrecji zwiercin

Fig. 4. Effect of mechanical load on the value of cuttings accretion

Zredukowanie siły mechanicznej działającej na zwierciny wpływa na opóźnienie zjawiska akrecji. Akrecja zwiercin przy zredukowanym obciążeniu zachodzi znacznie wolniej i osiąga znacznie niższe wartości. Maksymalna wartość akrecji przy oddziaływaniu pręta stalowego lekkiego wynosiła 73,8\% (rys. 4). Dla porównania wartość akrecji przy zastosowaniu pręta stalowego ciężkiego wzrosła do $94,8 \%$ (rys. 4). 
Uzyskane wyniki wskazują, że zanim dojdzie do akrecji i aglomeracji, musi wystąpić działanie na zwierciny siły o określonej wartości, obniżenie jej wartości może zminimalizować tendencję zwiercin do akrecji.

\section{Badania laboratoryjne nad opracowaniem środków przeciwakrecyjnych}

Badania nad opracowaniem składu kompozycji przeciwakrecyjnej rozpoczęto od wstępnej selekcji dostępnych środków powierzchniowo czynnych. Badania doboru tych środków prowadzono, opierając się na ich właściwościach oraz badaniach napięcia powierzchniowego. Po dokonaniu wstępnego doboru środków powierzchniowo czynnych wykonano szereg badań laboratoryjnych określających efektywność zapobiegania akrecji przez zastosowane środki chemiczne. Badania nad opracowaniem środka przeciwakrecyjnego prowadzono w środowisku płuczki potasowo-polimerowej (tab. 5), wprowadzając do niej środki powierzchniowo czynne w ilości 1\% obj. Wartości akrecji zwiercin w zależności od zastosowanych środków przedstawiono w tabeli 4 i na rysunku 5.

Oceny efektywności działania użytych środków dokonywano na podstawie przyrostu zawartości zwiercin na stalowym pręcie rolowanym $\mathrm{w}$ autoklawie w środowisku płuczki potasowo-polimerowej. Pierwsze przeprowadzone testy w płuczce potasowo-polimerowej wykazały ponad 95-procentową akrecję zwiercin (tab. 4, fot. 14, rys. 5). Zastosowane środki w zależności od swoich właściwości w różny sposób wpływały na zjawisko akrecji. Wprowadzenie do płuczki środka RD doprowadziło do niewielkiego ograniczenia przyrostu zwiercin na powierzchni stalowego pręta, wartość akrecji obniżyła się do
81,92\% (rys. 5). Nieznacznie większą efektywnością wykazał się środek K30, którego zastosowanie spowodowało ograniczenie akrecji do 72,04\% (tab. 4, fot. 18, rys. 5). W badaniach nad doborem środków o działaniu przeciwakrecyjnym testom poddano także środki stosowane w płuczkach wiertniczych jako inhibitory hydratacji skał ilasto-łupkowych: poliglikol i R2600. W wyniku przeprowadzonych badań stwierdzono, że środki te pomimo zapobiegania hydratacji skał ilasto-łupkowych nie wpływają na ograniczenie akrecji zwiercin. Wartość akrecji w płuczce $\mathrm{z}$ dodatkiem $1 \%$ poliglikolu wynosiła $74,92 \%$ (tab. 4 , fot. 16 , rys. 5), a w płuczce z dodatkiem R2600 - 69,54\% (rys. 5). W celach porównawczych równolegle $\mathrm{z}$ badaniami doboru środków przeciwakrecyjnych prowadzono badania określenia efektywności środka stosowanego w polskim wiertnictwie do przeciwdziałania oblepianiu świdra zwiercinami DW.

Dodatek do płuczki potasowo-polimerowej środka DW pozwolił na zmniejszenie akrecji zwiercin do poziomu około

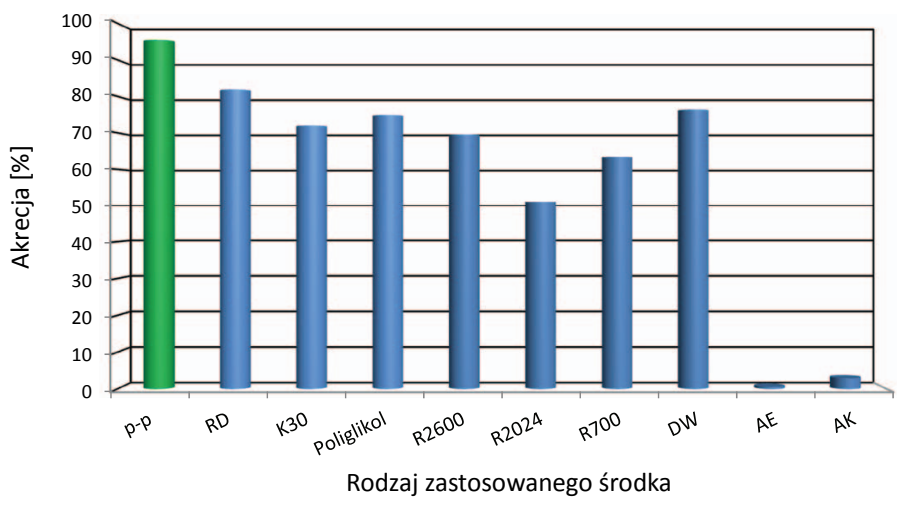

Rys. 5. Wpływ dodatku środków chemicznych na akrecję zwiercin w środowisku płuczki potasowo-polimerowej

Fig. 5. Influence of chemical agents on the cuttings accretion in the environment of potassium-polymer mud

Tabela 4. Wpływ dodatku środków chemicznych na akrecję zwiercin w środowisku płuczki potasowo-polimerowej

Table 4. Influence of chemical agents on the cuttings accretion in the environment of potassium-polymer mud

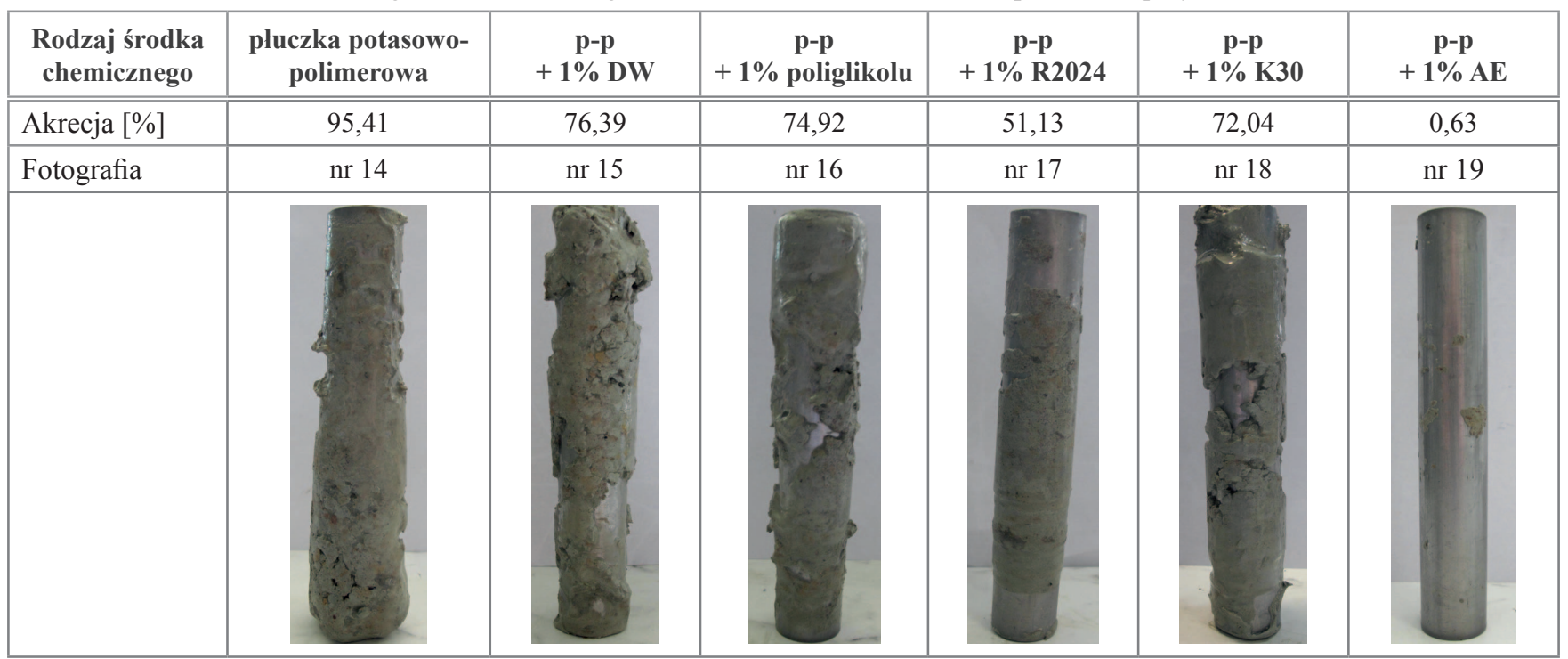


76,39\% (tab. 4, fot. 15). Spośród przebadanych środków największą efektywnością w działaniu wykazały się środki takie jak R2024 i R700, po których użyciu wartości akrecji wynosiły odpowiednio 51,13\% i 63,44\% (rys. 5).

W wyniku dalszych badań, łączenia ze sobą poszczególnych składników w różnych proporcjach objętościowych, otrzymano dwa nowe środki o działaniu przeciwakrecyjnym: środek AE i Antyacretion AK. Zastosowanie do płuczki potasowo-polimerowej nowo opracowanych środków skutecznie ograniczyło przyklejanie zwiercin do stalowej powierzchni pręta. Zmierzona wartość akrecji w płuczce z dodatkiem 1\% AE po czasie 20 min obniżyła się do $0,63 \%$ (tab. 4, fot. 19, rys. 5). Nieznacznie wyższe wartości akrecji - 2,92\% odnotowano po zastosowaniu środka AK (rys. 5).

Ograniczenie akrecji zwiercin w płuczce wodnodyspersyjnej przez opracowany środek prawdopodobnie zachodzi w wyniku zwilżania i pokrywania powierzchni metalowej pręta i zwiercin ilastych hydrofobową warstewką zapobiegającą łączeniu się uwodnionych cząsteczek ilastych w większe aglomeraty i zmniejszającą ich przyczepność do powierzchni stalowych przewodu wiertniczego.

Opracowany środek może być stosowany do wodnodyspersyjnych płuczek wiertniczych podczas przewiercania reaktywnych formacji skał ilasto-łupkowych. Użycie tego środka wpływa na znaczne ograniczenie zjawiska akrecji zwiercin na powierzchni stalowej pręta.

\section{Badania wpływu opracowanych środków przeciwakrecyjnych na właściwości pluczki potasowo-polimerowej}

Podstawowym zadaniem środka przeciwakrecyjnego dodawanego do płuczki jest zapobieganie gromadzeniu się i przyklejaniu zwiercin do powierzchni świdra i przewodu wiertniczego. Dozowany do płuczek wiertniczych środek przeciwakrecyjny

Tabela 5. Wpływ dodatku środków przeciwakrecyjnych na właściwości płuczki potasowo-polimerowej

Table 5. Influence of anti-accretion agents on the potassium-polymer mud properties

\begin{tabular}{|c|c|c|c|c|c|c|c|c|c|}
\hline \multirow{3}{*}{$\begin{array}{c}\mathrm{Nr} \\
\text { płuczki }\end{array}$} & \multirow{3}{*}{\multicolumn{2}{|c|}{$\begin{array}{c}\text { Skład płuczki } \\
{[\%]}\end{array}$}} & \multirow{3}{*}{$\begin{array}{c}\text { Gęstość } \\
{\left[\mathrm{kg} / \mathrm{m}^{3}\right]} \\
\rho \\
\end{array}$} & \multirow{2}{*}{\multicolumn{2}{|c|}{$\begin{array}{l}\text { Lepkość } \\
{[\mathrm{mPa} \cdot \mathrm{s}]}\end{array}$}} & \multirow{3}{*}{$\begin{array}{c}\begin{array}{r}\text { Granica } \\
\text { plynięcia }\end{array} \\
{[\mathrm{Pa}]} \\
\tau_{y}\end{array}$} & \multirow{3}{*}{$\begin{array}{c}\begin{array}{c}\text { Wytrzymałość } \\
\text { strukturalna }\end{array} \\
{[\mathrm{Pa}]} \\
\mathrm{I} / \mathrm{II} \\
\end{array}$} & \multirow{3}{*}{$\begin{array}{c}\text { Filtracja } \\
{\left[\mathrm{cm}^{3}\right]}\end{array}$} & \multirow{3}{*}{ pH } \\
\hline & & & & & & & & & \\
\hline & & & & $\eta_{p l}$ & $\eta_{s}$ & & & & \\
\hline 1 & $\begin{array}{l}\text { Biocyd } \\
\text { XCD } \\
\text { CMC LV } \\
\text { PHPA } \\
\text { KCl } \\
\text { Blokator } \\
\text { Baryt }\end{array}$ & $\begin{array}{l}0,2 \\
0,3 \\
2,0 \\
0,2 \\
7,0 \\
7,0\end{array}$ & 1260 & 36 & 58,0 & 21,0 & $4,3 / 5,7$ & 4,0 & 9,5 \\
\hline 2 & $\begin{array}{l}\text { Płuczka } 1 \\
+ \text { ił (eocen) }\end{array}$ & 5,0 & 1290 & 39 & 63,5 & 23,4 & $4,3 / 5,7$ & 3,6 & 9,3 \\
\hline 3 & $\begin{array}{l}\text { Płuczka } 2 \\
+\mathrm{AE}\end{array}$ & 0,5 & 1290 & 39 & 63,0 & 23,0 & $4,3 / 5,7$ & 3,6 & 9,3 \\
\hline 4 & $\begin{array}{l}\text { Płuczka } 2 \\
+\mathrm{AE}\end{array}$ & 1,0 & 1290 & 39 & 63,0 & 23,0 & $4,3 / 5,7$ & 3,6 & 9,3 \\
\hline 5 & $\begin{array}{l}\text { Płuczka } 2 \\
+\mathrm{AE}\end{array}$ & 2,0 & 1290 & 39 & 64,0 & 24,3 & $4,3 / 5,7$ & 3,6 & 9,3 \\
\hline 6 & $\begin{array}{l}\text { Płuczka } 2 \\
+\mathrm{AE}\end{array}$ & 3,0 & 1290 & 39 & 64,5 & 24,4 & $4,3 / 5,7$ & 3,4 & 9,2 \\
\hline 7 & $\begin{array}{l}\text { Płuczka } 2 \\
+\mathrm{AE}\end{array}$ & 5,0 & 1290 & 39 & 65,5 & 25,3 & $4,3 / 6,2$ & 3,2 & 9,2 \\
\hline 8 & $\begin{array}{l}\text { Płuczka } 2 \\
+ \text { AK }\end{array}$ & 0,5 & 1290 & 39 & 63,5 & 23,4 & $4,3 / 5,7$ & 3,6 & 9,3 \\
\hline 9 & $\begin{array}{l}\text { Płuczka } 2 \\
+ \text { AK }\end{array}$ & 1,0 & 1290 & 39 & 63,5 & 23,4 & $4,3 / 5,7$ & 3,6 & 9,3 \\
\hline 10 & $\begin{array}{l}\text { Płuczka } 2 \\
+ \text { AK }\end{array}$ & 2,0 & 1290 & 40 & 64,5 & 23,4 & $4,3 / 5,7$ & 3,6 & 9,3 \\
\hline 11 & $\begin{array}{l}\text { Płuczka } 2 \\
+ \text { AK }\end{array}$ & 3,0 & 1290 & 40 & 65,0 & 24,0 & $4,3 / 6,2$ & 3,4 & 9,3 \\
\hline 12 & $\begin{array}{l}\text { Płuczka } 2 \\
+ \text { AK }\end{array}$ & 5,0 & 1290 & 40 & 65,5 & 24,4 & $4,3 / 6,7$ & 3,4 & 9,4 \\
\hline
\end{tabular}


nie powinien negatywnie wpływać na właściwości płuczki wiertniczej. Mając na względzie powyższe, przeprowadzono badania określenia wpływu dodatku środka przeciwakrecyjnego na właściwości płuczki potasowo-polimerowej. Wymienione środki wprowadzano do płuczki w ilości od 0,5\% do 5\% obj. Po dodaniu do płuczek środków przeciwakrecyjnych określano ich właściwości i porównywano do właściwości płuczki potasowo-polimerowej przed dodaniem środków. Wyniki badań przedstawiono w tabeli 5 .

Przeprowadzone badania laboratoryjne wykazały, że środek przeciwakrecyjny AE przy dodatku od $0,5 \%$ do $2 \%$ nie wpływa negatywnie na właściwości płuczki. Po wprowadzeniu środka do płuczki nie obserwuje się zmian parametrów reologicznostrukturalnych, wzrostu filtracji ani zmian w wartościach $\mathrm{pH}$. Przy dodatku zwiększonym do 5\% obj. można zauważyć niewielki wzrost lepkości pozornej - z 63 do $65,5 \mathrm{mPa} \cdot \mathrm{s}$ i granicy płynięcia - z 23 do 25,3 Pa (tab. 5). Występuje także niewielkie obniżenie wartości pH płuczki - z 9,3 na 9,2 i filtracji - z 3,6 do 3,2 $\mathrm{cm}^{3} / 30 \mathrm{~min}$. Wpływ środka AK na właściwości płuczki jest podobny. Dodatek do $2 \%$ obj. nie powoduje wyraźnych zmian we właściwościach płuczki potasowo-polimerowej. Przy wyższych stężeniach możliwy jest niewielki wzrost lepkości pozornej i granicy płynięcia. Wartość pH płuczki nie ulega zmianie, a wartość filtracji przy dodatku 5\% obj. obniża się z 3,6 do 3,4 cm³/30 $\min$ (tab. 5).

\section{Badania efektywności opracowanych środków przeciwakrecyjnych w pluczce otworowej}

Badania efektywności opracowanych środków przeciwakrecyjnych wykonywano dodatkowo w środowisku płuczki stosowanej do wiercenia otworu K1 do głębokości $1215 \mathrm{~m}$. Właściwości płuczki z dodatkiem środków przeciwakrecyjnych przedstawiono w tabeli 6 .

Do wiercenia otworu K1 do głębokości 1215 m stosowano płuczkę glikolowo-potasową. Płuczka o gęstości $1200 \mathrm{~kg} / \mathrm{m}^{3}$ posiadała lepkość plastyczną $31 \mathrm{~m}$ · Pas, granicę płynięcia 14,3 Pa.

Tabela 6. Wpływ środków przeciwakrecyjnych na właściwości płuczki stosowanej do wiercenia otworu K1

Table 6. Influence of anti-accretion agents on the properties of mud used during drilling hole K1

\begin{tabular}{|c|c|c|c|c|c|c|c|c|c|}
\hline \multirow{3}{*}{$\begin{array}{c}\mathrm{Nr} \\
\text { płuczki }\end{array}$} & \multirow{3}{*}{\multicolumn{2}{|c|}{ Rodzaj płuczki }} & Gęstośćć & \multirow{2}{*}{\multicolumn{2}{|c|}{$\begin{array}{l}\text { Lepkość } \\
{[\mathrm{mPa} \cdot \mathrm{s}]}\end{array}$}} & \multirow{3}{*}{$\begin{array}{c}\begin{array}{c}\text { Granica } \\
\text { plynięcia }\end{array} \\
{[\mathrm{Pa}]} \\
\tau_{y} \\
\end{array}$} & \multirow{3}{*}{$\begin{array}{c}\text { Wytrzymałość } \\
\text { strukturalna }\end{array}$} & \multirow{3}{*}{$\begin{array}{c}\text { Filtracja } \\
{\left[\mathrm{cm}^{3}\right]}\end{array}$} & \multirow{3}{*}{ pH } \\
\hline & & & \multirow{2}{*}{$\frac{\left[\mathrm{kg} / \mathrm{m}^{3}\right]}{\rho}$} & & & & & & \\
\hline & & & & $\eta_{p l}$ & $\eta_{s}$ & & & & \\
\hline 1 & Płuczka gl & asowa & 1200 & 31 & 46 & 14,3 & $1,9 / 2,9$ & 3,6 & 9,1 \\
\hline 2 & $\begin{array}{l}\text { Płuczka } 1 \\
+ \text { DW }\end{array}$ & 1,0 & 1290 & 30 & 45,5 & 14,8 & $1,9 / 2,9$ & 3,6 & 9,1 \\
\hline 3 & $\begin{array}{l}\text { Płuczka } 1 \\
+\mathrm{AE}\end{array}$ & 1,0 & 1290 & 31 & 46 & 14,3 & $1,9 / 2,4$ & 3,4 & 9,0 \\
\hline 4 & $\begin{array}{l}\text { Płuczka } 1 \\
+ \text { AK }\end{array}$ & 1,0 & 1290 & 32 & 46,5 & 13,9 & $1,9 / 2,9$ & 3,4 & 9,2 \\
\hline
\end{tabular}

Tablica 7. Wartości akrecji zwiercin w środowisku płuczki pobranej podczas wiercenia otworu K1 do głębokości $1215 \mathrm{~m}$

Table 7. The values of cuttings accretion in drilling mud from K1 borehole at depth $1215 \mathrm{~m}$

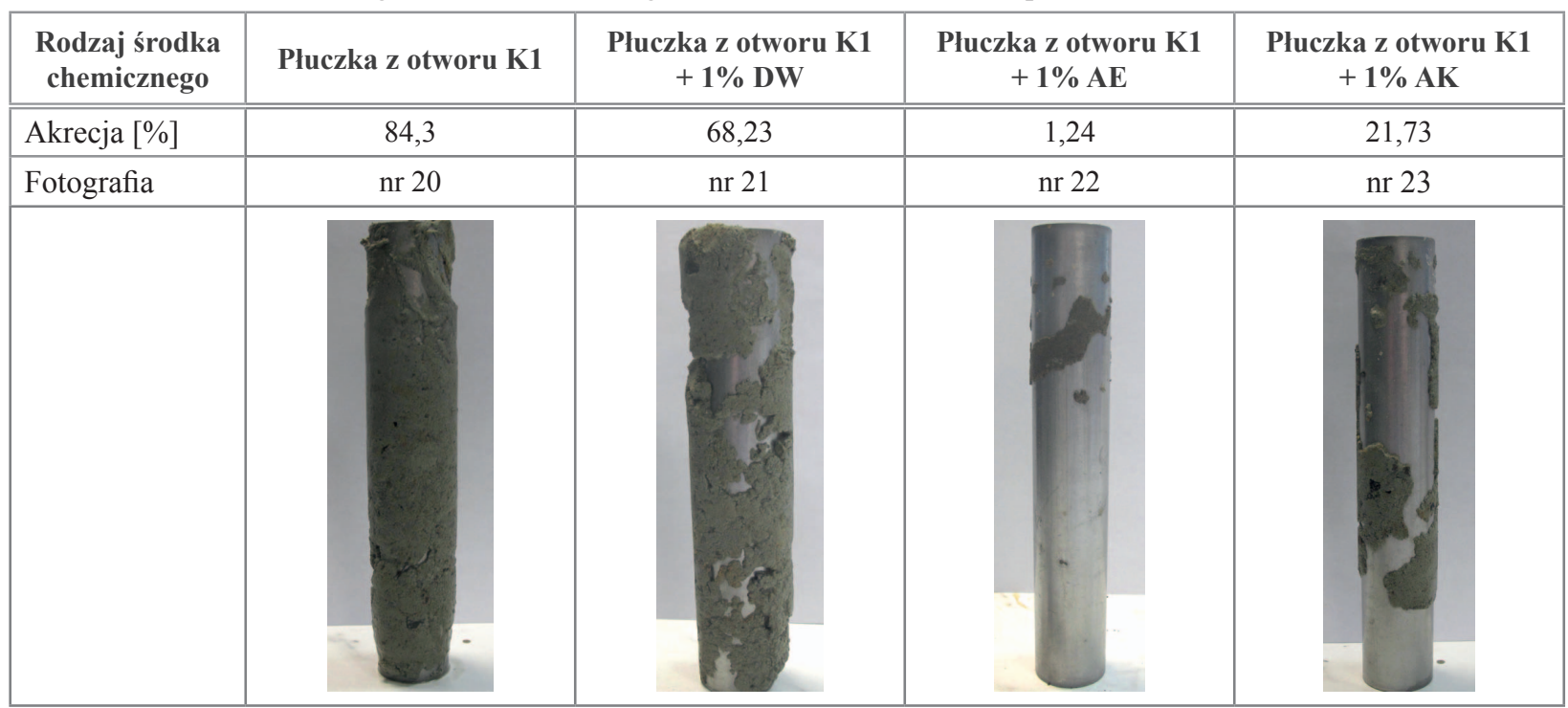


Analiza chemiczna płuczki wykazała, że płuczka zawierała $38,4 \mathrm{~g} / \mathrm{dm}^{3}$ jonów potasu, $39,3 \mathrm{~g} / \mathrm{dm}^{3}$ jonów chlorkowych. Stwierdzono także $0,2 \%$ polimeru PHPA i 3,7\% poliglikolu. Zawartość fazy stałej w płuczce wynosiła $12 \%$, a zawartość aktywnych części bentonitu 3,6\%.

Badania akrecji przeprowadzono dla płuczki pobranej z otworu K1 oraz dla płuczki otworowej z dodatkiem środków przeciwakrecyjnych: AE i AK oraz w celach porównawczych dla płuczki z dodatkiem środka DW. Wykonane testy akrecyjne po czasie 20 min wykazały, że ilość zwiercin przyklejonych do stalowego pręta w płuczce otworowej wynosiła $84,3 \%$ (tab. 7, fot. 20, rys. 6). Wprowadzenie do płuczki $1 \%$ środka AE spowodowało obniżenie akrecji do wartości $1,24 \%$ (tab. 7 , fot. 22 , rys. 6). Nieznacznie wyższą wartość akrecji $-21,73 \%$ (tab. 7 , fot. 23 , rys. 6) otrzymano w przypadku wykorzystania płuczki z dodatkiem środka AK. Natomiast zastosowanie w płuczce środka DW pozwoliło na obniżenie akrecji w stosunku do płuczki bez dodatku środków o 19\% (tab. 7, fot. 22, rys. 21).

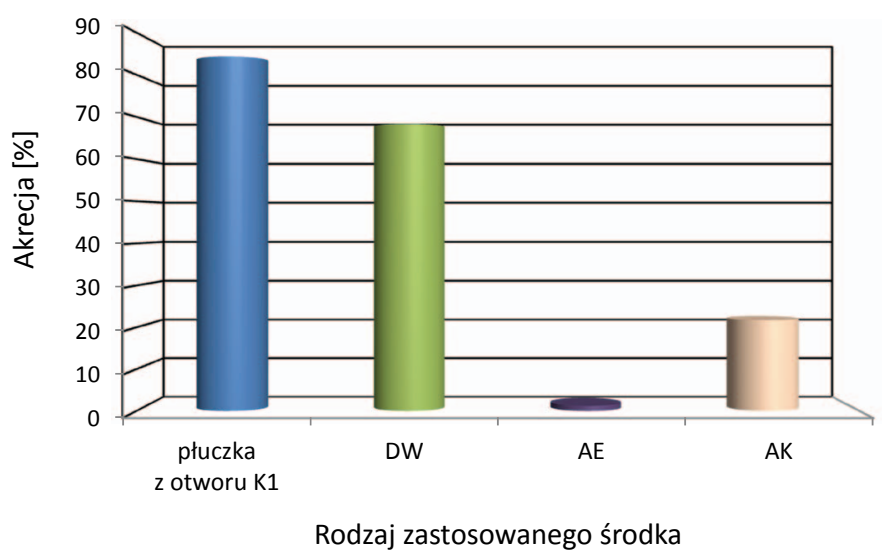

Rys. 6. Wartości akrecji zwiercin w środowisku płuczki pobranej podczas wiercenia otworu K1 do głębokości $1215 \mathrm{~m}$

Fig. 6. The values of cuttings accretion in drilling mud from K1 borehole at depth $1215 \mathrm{~m}$

\section{Wnioski}

Przeprowadzone badania laboratoryjne oraz dokonana analiza wyników badań pozwoliły na sformułowanie następujących wniosków:

1. Wykonane badania wykazały, że akrecja w dużym stopniu zależna jest od rodzaju przewiercanych skał łupkowych. Analizując przeprowadzone badania składu mineralnego oraz otrzymane wartości akrecji, można stwierdzić, że łupek eoceński ze względu na swoje właściwości charakteryzuje się znacznie większą tendencją niż łupek mioceński do przyklejania się do stalowej powierzchni w środowisku płuczek wodnodyspersyjnych.
2. Badania wpływu wielkości zwiercin na akrecję przeprowadzono dla trzech klas wielkości zwiercin łupku eoceńskiego, tj.: 1,4-2 mm, 2-5 mm i 5-7 mm. Na podstawie otrzymanych wyników ustalono, że wraz ze wzrostem wielkości zwiercin następuje opóźnienie procesu zachodzącej akrecji oraz obniżenie jej wartości. Zwierciny o rozmiarach od $5 \mathrm{~mm}$ do $7 \mathrm{~mm}$ wymagają znacznie dłuższego czasu oddziaływania płuczki i obciążenia mechanicznego do rozpoczęcia procesu akrecji zwiercin. Najwyższe wartości akrecji uzyskano w przypadku zwiercin o rozmiarach od $2 \mathrm{~mm}$ do $5 \mathrm{~mm}$.

3. Zredukowanie siły mechanicznej działającej na zwierciny wpływa na opóźnienie zjawiska akrecji. Akrecja zwiercin przy zredukowanym obciążeniu zachodzi znacznie wolniej i osiąga znacznie niższe wartości. Maksymalna wartość akrecji przy oddziaływaniu pręta stalowego lekkiego wynosiła 73,8\%. Dla porównania wartość akrecji przy zastosowaniu pręta stalowego ciężkiego wzrosła do $94,8 \%$. Otrzymane wyniki wskazują, że zanim dojdzie do akrecji i aglomeracji, musi wystąpić działanie na zwierciny siły o określonej wartości, obniżenie jej wartości może zminimalizować tendencję zwiercin do akrecji.

4. Uzyskane wyniki badań zostały poddane analizie, umożliwiającej opracowanie składu środka przeciwakrecyjnego, który może być stosowany jako dodatek do wodnodyspersyjnych pluczek wiertniczych w celu zapobiegania oblepianiu świdra i akrecji zwiercin.

5. Uwzględniając wyniki przeprowadzonych testów akrecyjnych oraz wpływ opracowanego środka AE na właściwości płuczki, ustalono, że optymalne ilości środka do zapobiegania akrecji zwiercin w środowisku wodnodyspersyjnych płuczek wiertniczych powinny wynosić od $1 \%$ do $3 \%$ obj. w stosunku do całkowitej objętości płuczki.

6. Ograniczenie akrecji zwiercin w płuczce wodnodyspersyjnej przez opracowany środek prawdopodobnie zachodzi w wyniku pokrywania powierzchni metalowej i zwiercin ilastych hydrofobową warstewką zapobiegającą łączeniu się uwodnionych cząsteczek ilastych w większe aglomeraty i zmniejszającą ich przyczepność do powierzchni stalowych przewodu wiertniczego.

7. Skuteczność działania opracowanego środka AE została sprawdzona w płuczkach sporządzonych w laboratorium oraz płuczce otworowej pobranej podczas wiercenia otworu. Przeprowadzone badania efektywności opracowanego środka w środowisku płuczki wiertniczej wykazały wysoką skuteczność jego działania w zapobieganiu akrecji zwiercin. Zastosowanie opracowanego środka AE do płuczki otworowej pozwoliło na ponad 90-procentowe zredukowanie akrecji zwiercin w porównaniu do płuczki bez dodatku tego typu środków. W badaniach potwierdzono także 
jego znacznie wyższą efektywność od obecnie stosowanego w polskim wiertnictwie środka do zapobiegania oblepianiu świdra DW.

Artykuł powstał na podstawie pracy statutowej pt.: Badania laboratoryjne nad doborem środków przeciwakrecyjnych do płuczek wiertniczych - praca INiG - PIB na zlecenie MNiSW; nr zlec. 0015/KW/18, nr archiwalny: DK-4100-15/18.

\section{Literatura}

Black A.D., Bland R.G., Curry D., Ledgerwood L.W., Robertson H., Judzis A., Grant T., 2008. Optimization of Deep-Drilling Performance with Improvements in Drill-Bit and DrillingFluid Design. Society of Petroleum Engineers. DOI: 10.2118/112731-MS.

Cliffe S., Young S., 2008. Agglomeration and Accretion of Drill Cuttings in Water-Based Fluids. American Association of Drilling Engineers, AADE-08-DF-HO-10.

Ewy R.T., Morton E.K., 2009. Wellbore-Stability Performance of Water-Based Mud Additives. Society of Petroleum Engineers. DOI: 10.2118/116139-PA.

Hariharan P.R., Cooper G.A., Hale A.H., 1998. Bit Balling Reduction by Electro-Osmosis While Drilling Shale Using a Model BHA (Bottom Hole Assembly). Society of Petroleum Engineers. DOI: 10.2118/39311-MS

He S., Liang L., Zeng Y., Ding Y., Lin Y., Liu X., 2016. The influence of water-based drilling fluid on mechanical property of shale and the wellbore stability. Petroleum, 2(1): 61-66. DOI: 10.1016/j. petlm.2015.12.002.

Jasiński B., 2015. Comparison of the effect of inhibited drilling muds parameters on the physical and mechanical properties of shale rocks. Nafta-Gaz, 6: 418-424.

Judzis A., Black A.D., Curry D.A., Meiners M.J., Grant T., Bland R.G., 2007. Optimization of Deep Drilling Performance; Benchmark Testing Drives ROP Improvements for Bits and Drilling Fluids. Society of Petroleum Engineers. DOI: 10.2118/105885-MS.

Ma C., Yang Y., Li L., 2012. Study on Drilling Fluid Technology of Eliminating Bit Balling by Changing Wettability. Advanced Materials Research, 542-543: 1083-1086. DOI: 10.4028/www. scientific.net/AMR.542-543.1083.

Mat M.R., Bin Zakaria M.Z., Radford S., Eckstrom D., 2002. Innovative Low-Friction Coating Reduces PDC Balling and Doubles ROP Drilling Shales with WBM. Society of Petroleum Engineers. DOI: 10.2118/74514-MS.

Mettath S., Stamatakis E., Young S., De Stefano G., 2011. The Prevention and Cure of Bit Balling in Water-Based Drilling Fluids. American Association of Drilling Engineers, AADE-11-NTCE-28.

Onuoha I.E.O., Bilgesu H.I., Ameri S., 2011. Study of Drilling Fluid Additives and Their Impact on Smectite Inhibition, Marcellus Shale Inhibition, and Filtration \& Rheological Properties of Bentonite Based Drilling Fluids. Society of Petroleum Engineers. DOI: $10.2118 / 149271-\mathrm{MS}$
Rahmani R., Ferrell R.E., Smith J.R., 2016. Multiscale Imaging of Fixed-Cutter-Drill-Bit-Generated Shale Cuttings. Society of Petroleum Engineers. DOI: 10.2118/176028-PA.

Schnuriger M., Cuillier B., Tilleman D., Rose K., 2017. Curved Nozzle Design for PDC Bits Enhances Hydraulics for Bit Cleaning and Cooling Improvements. Society of Petroleum Engineers. DOI: 10.2118/184734-MS.

Smith L., Mody F.K., Hale A., Romslo N., 1996. Successful Field Application of an Electro-Negative Coating to Reduce Bit Balling Tendencies in Water Based Mud. Society of Petroleum Engineers. DOI: 10.2118/35110-MS

Uliasz M., Zima G., Jasiński B., Szajna A., 2018. Ocena wpływu poliwinyloaminy na inhibitujące właściwości płuczki wiertniczej. Nafta-Gaz, 9: 669-675. DOI: 10.18668/NG.2018.09.05.

Van Oort E., 2017. Shale Stabilization by High-Salinity Formate Drilling Fluids. American Association of Drilling Engineers, AADE-17-NTCE-111.

Van Oort E., Ahmad M., Spencer R., Legacy N. 2015. ROP Enhancement in Shales through Osmotic Processes. Society of Petroleum Engineers. DOI: 10.2118/173138-MS.

Van Oort E., Bland R., Pessier R., 2000. Drilling More Stable Wells Faster and Cheaper with PDC Bits and Water Based Muds. Society of Petroleum Engineers. DOI: 10.2118/59192-MS.

Villabona-Estupiñán S., de Almeida Rodrigues J., Nascimento R.S.V., 2017. Understanding the clay-PEG (and hydrophobic derivatives) interactions and their effect on clay hydration and dispersion: A comparative study. Applied Clay Science, 143: 89-100. DOI: 10.1016/j.clay.2017.03.021.

Wells M., Marvel T., Beuershausen C., 2008. Bit Balling Mitigation in PDC Bit Design. Society of Petroleum Engineers. DOI:10.2118/114673-MS.

Yadav P.K., Ali S.S., Tawat N.A.A., Dhamen A.A.A., Jin G., 2016. Effect of Drilling Fluid on Rock Mechanical Properties at Near-Drilling Conditions: An Implication of Fluid Design on Wellbore Stability. Society of Petroleum Engineers. DOI: 10.4043/26460-MS.

Zhang Q., Jia W., Fan X., Liang Y., Yang Y., 2015. A review of the shale wellbore stability mechanism based on mechanical-chemical coupling theories. Petroleum, 1(2): 91-96. DOI: 10.1016/j. petlm.2015.06.005

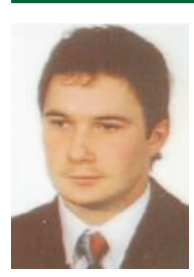

Mgr inż. Sławomir BŁAŻ

Starszy specjalista badawczo-techniczny w Zakładzie Technologii Wiercenia Instytut Nafty i Gazu - Państwowy Instytut Badawczy ul. Lubicz 25 A

31-503 Kraków

E-mail: slawomir.blaz@inig.pl 